Culture and Democracy 
"We are not free because of what we statically are, but insofar as we are becoming different from what we have been."

John Dewey

To Mum and Dad 


\section{Culture and Democracy}

Media, Space, and Representation

Clive Barnett 
(C) Clive Barnett, 2003

Transferred to Digital Print 2011

Edinburgh University Press Ltd

22 George Square, Edinburgh

\author{
Typeset in Sabon \\ by J\&L Composition, Filey, North Yorkshire \\ Printed and bound in Great Britain by \\ CPI Antony Rowe, Chippenham and Eastbourne
}

A CIP record for this book is available from the British Library

$$
\begin{aligned}
& \text { ISBN } 0748614001 \text { (hardback) } \\
& \text { ISBN } 0748613994 \text { (paperback) }
\end{aligned}
$$

The right of Clive Barnett to be identified as author of this work has been asserted in accordance with the Copyright, Designs and Patents Act 1988. 